\section{Catalogue of Forbidden} German Feature and Short Film Productions, original text by John F. Kelson, edited with new material selected by K. R. M. Short (198 pages, May 1996), lists 395 features, feature-length documentaries, and short films that were forbidden for public exhibition during the postwar occupation of Germany. Originally compiled as a tool for reeducating the population of the three western zones of occupation, this catalog is a pivotal document for understanding the policies of the occupying powers between 1945 and 1951. The book also includes a complete list of all films produced in Germany between 1933 and 1945 by the Propaganda Ministry. $\$ 75.00$. Greenwood Press, 88 Post Road West, Westport, CT 068815007. ISBN 0-313-30106-9.

\section{A Dictionary of Euphemisms, by R. W.} Holder ( 470 words, April 1996), defines those words or phrases that serve as mild substitutes for offensive, harsh, or blunt language. It provides etymological information whenever possible. For those in search of euphemisms, a thematic index brings together alternative expressions referring to bawds and pimps, bribery, death, defecation, narcotics, etc. $\$ 25.00$. Oxford University Pr., 198 Madison Ave., New York, NY 10016. ISBN 0-19-869275-7.

\section{The Ever-Changing Sky: A Guide to the} Celestial Sphere, by James B. Kaler ( 495 pages, July 1996), summarizes for nonspecialists the mechanics of terrestrial and planetary motions. This is not an observer's guide and, although geometric and trigonometric expressions have been minimized, they have not been eliminated entirely. Chapters cover constellations, precession, sunrise and sunset, sidereal time, tides, and light and the atmosphere. Archaeologists, historians of science, and paleoanthropologists will especially appreciate this guide. $\$ 39.95$. Cambridge University Pr., 40 w. 20th St., New York, NY 10011-4211. ISBN 0-521-38053-7.

\section{Morality and Social Order in Television} Crime Drama, by John Sumser (192 pages,
July 1996), examines the social content of prime-time mystery dramas from the late 1960 s to the mid-1980s in order to find answers to the following questions: Do newer dramas have fewer clear-cut explanations than earlier programming? Are explanations in the newer shows more explicitly moralistic? Do differences in character types (detectives, villains, rich people) reflect social rules governing the just distribution of power, wealth, and prestige? This could have been a dry, sociological exercise, but the author expresses his findings in terms understandable to fans of Jim Rockford, Jessica Fletcher, and Danno Williams. A final chapter looks at how crime shows of the 1990 s increasingly reflect a moral ambiguity that has replaced the moral certainties of an earlier era. $\$ 34.50$. McFarland \& Co., Box 611, Jefferson, NC 28640. ISBN 0-7864-0125-7.

If crime movies are more to your liking, check out Gangster Films: A Comprehensive, Illustrated Reference to People, Films and Terms, by Michael L. Stephens (377 pages, July 1996), an encyclopedic guide to the genre. \$49.95. McFarland. ISBN 0-78640046-3.

Online Law, edited by Thomas J. Smedinghoff ( 544 pages, May 1996), addresses the complexities and complications of conducting online transactions. Commissioned by the Software Publishers Association, this book offers background and guidance on such topics as online contracts, eavesdropping on employee e-mail, copyright, digital signatures, digital cash, online piracy, vagaries of jurisdiction, advertising content, and security. A good acquisition not only for business and law libraries, but also for the resident Webmaster. $\$ 34.95$. AddisonWesley, One Jacob Way, Reading, MA 01867. ISBN 0-201-48980-5.

George Eberbart is editor and compiler of The Whole Library Handbooks for ALA Editions (1991 1995). He served as editor of C\&RL News from 1980 to 1990 . 
The Oxford English-Hebrew Dictionary, edited by N. S. Doniach and A. Kahane (1091 pages, May 1996), covers many levels of language from the formal and poetic to colloquial language and slang. Its emphasis is on words in Modern Hebrew that are actually in use, rather than on newly coined words based on biblical roots, but which have never taken hold in actual usage. Hebrew equivalents are shown for many English colloquial phrases and compound words, while explanations of subsenses are given to differentiate English meanings. Sample sentences are frequently provided. $\$ 65.00$. Oxford University Pr., 198 Madison Ave., New York, NY 10016. ISBN 0-19-864322-5.

\section{Phonetic Symbol Guide, by} Geoffrey K. Pullum and William A. Ladusaw (320 pages, $2 \mathrm{~d}$ ed., 1996), covers the many changes and new proposals for phonetic symbols introduced over the past ten years by the International Phonetic Association (IPA), as well as many non-IPA phonetic symbols. Symbols are arranged by their shape and graphic relationship to other symbols. This guide clearly illustrates the origin and usage of such symbols as the hooktop b, the reversed epsilon, and the long-leg turned $\mathrm{m}$. Diacritical marks are also described, including underbar, retraction sign, northeast arrow, and subscript seagull. Supplemented by a glossary, bibliography, symbol charts, and three indexes. \$13.95, paper University of Chicago Pr., 11030 S. Langley Ave., Chicago, IL 60628. ISBN 0-226-68535-7.

The Ultimate Spy Book, by H. Keith Melton (176 pages, April 1996), depicts the missions, equipment, and operatives in the world of espionage. The book's value lies in the photographs showing concealed cameras, listening devices, fake IDs, lockpicks, suitcase radios, concealed weapons, and other gadgets actually used in spy operations. A handy visual companion for reading spy novels or histories of intelligence agencies. \$29.95. DK Publishing, 95 Madison Ave., New York, NY 10016. ISBN 0-7894-0443-5.

\section{The Cambridge Illustrated History of Ar-} chaeology, edited by Paul G. Bahn (386 pages, October 1996), captures the excitement and controversy of the subject in language accessible to nonspecialists. Bahn traces the history of the profession from its uncertain origins in antiquity to the latest discoveries and theories in physical anthropology. The illustrations are well chosen and uncommon, while the text is designed to show how archaeological views of the past have evolved, meandered, and misfired in the past 500 years. The final chapter discusses current trends and problems, including gender-aware archaeology, the rights of indigenous peoples, looting and forgery, cultural tourism. and public education. \$39.95. Cambridge University Press, 40 W. 20th St., New York, NY 10011-4211. ISBN 0-521-45498-0.

Visions of Angels and Tales of Bowmen: The Angels of Mons, by Kevin McClure (24 pages, January 1996), reexamines the legend that at the Battle of Mons in August 1914 an "angel of the Lord" or a "comrade in white" or "spectral horsemen" was seen by retreating units of the British Expeditionary Force. A month later a short story, "The Bowmen," was published by novelist Arthur Machen in which he invented ghostly longhowmen from the Battle of Agincourt coming to aid the British. Machen always claimed he made the story up and that all angels-of-Mons tales derived from his fiction. However, McClure has unearthed some evidence from diaries and other accounts that contradicts this. An intriguing historical footnote for World War I and psychic collections. Available from Kevin McClure for $\$ 5.00$ (money orders only), 23 Strawberrydale Ave., Harrogate, North Yorkshire, HG1 5EA, England.

\section{J. C. Dana Award deadline moved up}

The deadline date for entries for the 1997 John Cotton Dana Awards, mentioned in CERL News (October 1996), has been moved to January 31, 1997. 


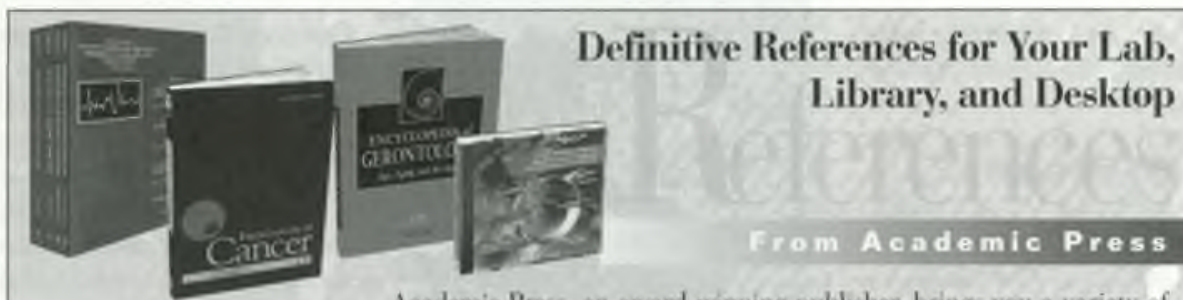

\section{Encyclopedia of Gerontology}

Age, Aging, and the Aged

Fidior-in-Chief

\section{James E. Birren}

This two-volume work prounies to be the unost comprehensive work on age, aging, and the aged available.

Key Feafures

- 139 articles, $8 \frac{1}{2} \times 11^{\circ}$ format

- 125 figures, 100 ubles. illustrations, and photos

- 600 glossary entries, 7,500 entry index

Two-Volume Set

Prepublication Prices \$250.00* Augu-1 1996. $1+7+$ pp. $\$ \$ 00.00$ ISBN 0-12-226860-1

-Valid through December 31. 1990.

Vinit our gerontology webmite at www.apnet.com/aging/

\section{Database of Palladium Chemistry}

Reactions, Caralyuc Cycles, and Chemical Parameters CD-ROM Version 1.0

Jean-Lue Malleron and Alain Juin

A collection of data presented in a searchable and accessible format. this CD-ROM will be of enormous value. The database contains 3500 reactions, 85 types of mechanisms, as well as the chemical parameters related to them. Approximately 500-700 reactions are added each year.

\section{CI)-ROM: $\$ 875,00$}

November 1096/ISBN= 0-12- $+60700-0$ System Requirements:

PC with 80386 or higher +MIB RAM, VCA monitor, 8MB hand di-k.

MS-DOS 30 or latex. Windows 3.1

or later, mouse or pointing device.
Academic Press, an award-wimning publisher, brings vou a variety of major reference work this Fall. Designed to inform, educate and enlighten, these references will provide you with the sources you need to perform your job wih ease.

\section{The Handbook} of Infrared and Raman Spectra of Inorganic Compounds and Organic Salts

Richard A. Nyquist,

Ronald 0, Kagel.

Curtis L. Puzig and

\section{Anne Leugers}

This four-volume handbook presents unique data of infrared and comparative Raman spectra and promises to be extremely useful for the analysis of inorganic compounds and organic salts. With spectra charts and cross-indexing. this comprehensive four-volume set, based on the authors" extensive lifetime research. is an essential reference.

Four Volume Set

Prepublication Prices $\$ 850.00^{2}$

August $1996,118+\mathrm{pp}$.

$51000.00 / 15 B \mathrm{~N}: 0-12-523444-9$

- Valid derveget Decruber 31, 1996
I is Price: $\$ 1000.00$

\section{Encyclopedia of Cancer}

Fiditor-in-Chief

Joseph IR. Bertino

The Encyelopedia of Caneer is the authoritative reference source for the rapidly growing field of cancer rocarch and all associated fiedds. This containo 163 expresaly written articles exploring the causes. potential cares, and preverive measures of cancer. The Encyclopedia is easy to read. easy to nee, and meticulously covers all of the "bot" topice

\section{Key Fealures}

- Comprehensive table of contents and subject inder in each volume

- Each arricle includes a table of contents, glossary; defiuing paragraph, and extended bibliograpliy

Three-Volume Set

Prepublication Price: $\$ 399,00 \%$ October 1996, 2135 pp. $\$ 550.00$ ISBN 0-12-09.3230-X

"Valid through December 31. 1996

Visit our cancer website at www.apnet.com/oncology! thee-volume encyclopedia in cancer revearch.
AP

\section{Academic Press, Inc.} Order Fulfillment Dept. DM17915 6277 Sea Harbor Drive, Orlando, F. 32887 24.28 Oval Road, London NWI 7DX, U.K.

\section{Find us on the Web! http://www.apnet.com/}

Proes subject to change without notice 01986 by Academic Press, ine. Al Aights Feserved
In the U.S. and Canada

CALL TOL FAEE 1-800-321-5068

FAX: 1-800-874-6418

E-MAlL- apeacad.com

In Europe, CALL: 0181-300-3322

\footnotetext{
UK/KJ/TR/GEN $-15116 \quad 10 / 96$
} 